\title{
THE ASSOCIATION OF LIPOPROTEINS WITH THE INHIBITION OF STREPTOLYSIN S BY SERUM ${ }^{1}$
}

\author{
By GENE H. STOLLERMAN, ${ }^{2}$ ALAN W. BERNHEIMER, AND COLIN M. MAcLEOD \\ (From the Department of Microbiology, New York University College of Medicine and \\ College of Dentistry, New York)
}

(Submitted for publication July 25, 1950; accepted, September 26, 1950)

\section{INTRODUCTION}

In a previous report (1), it was suggested that the inhibition of streptolysin $S$ by human serum is due to a normal component of serum rather than to a specific antibody. This view was supported by the following observations. The titer of streptolysin $\mathrm{S}$ inhibitor in the serum of patients convalescent from acute streptococcal pharyngitis remained within normal limits and did not increase as would be expected if the inhibitor were an antibody. Similarly, there was no evidence in any case of rheumatic fever studied of a rise in the titer of inhibitor above normal levels despite the demonstration of a marked increase in antibodies to streptolysin $O$ and to streptokinase in the same sera. The serum of patients with rheumatic fever, on the contrary, showed a tendency for the inhibitor titer to fall below normal values during the peak of clinical symptoms, an observation originally made by Todd, Coburn and Hill (2).

It was considered of importance to determine the nature of streptolysin $S$ inhibitor since the above observations indicate that streptolysin $S$ is not antigenic in man and furthermore, it seems possible that the inhibition by serum may play a part in affording protection against this streptococcal toxin. In addition, further knowledge of the nature of the inhibitor may help to clarify the significance of the fall in titer which frequently occurs during severe rheumatic activity.

The recent, independent studies of Humphrey $(3,4)$ and the observations recorded in the present paper show that the sera of numerous animal species cause inhibition of streptolysin $S$ and that this property is associated with the serum

1 These studies were supported in part by grants from the Life Insurance Medical Research Fund and the Masonic Foundation for Medical Research and Human Welfare.

2 Fellow of the Dazian Foundation for Medical Research. protein fractions which contain lipids. The present study indicates also that serum phospholipids, particularly lecithin, play an important part in the inhibition, either as components of lipoproteins which may inhibit streptolysin $\mathrm{S}$, as stabilizing agents for lipoprotein complexes, or possibly in both capacities.

\section{MATERIALS AND METHODS}

Preservation of sera. Sera stored at $4^{\circ} \mathrm{C}$. for several weeks showed no change in titer of streptolysin $\mathrm{S}$ inhibitor. Storage for longer periods, however, resulted in an increased titer in several of the specimens tested. Some sera stored at $4^{\circ} \mathrm{C}$. for six months showed a two-fold rise in titer and in eight specimens of normal human serum, which had remained at this temperature for two years, the titer was approximately four times that of fresh, normal serum. Animal and human sera stored at $-20^{\circ} \mathrm{C}$. for six months showed no change in titer. Repeated freezing and thawing of sera did not affect the level of streptolysin $\mathrm{S}$ inhibitor.

Sera obtained from patients and from animals were stored at $4^{\circ} \mathrm{C}$., therefore, only in instances where the titrations were carried out within a few days after blood had been drawn. Storage at $-20^{\circ} \mathrm{C}$. was employed for sera that were kept for longer periods. The addition of merthiolate as a preservative, in a dilution of 1:5000, did not affect the level of inhibitor. The titer in oxalated or citrated plasma, either fresh or after storage at $-20^{\circ} \mathrm{C}$. was the same as that of fresh serum separated from the same sample of blood.

Titration methods. The details of the method employed for the titration of streptolysin $S$ inhibitor have been described elsewhere (1). Streptolysin S was prepared by the method of Bernheimer and Rodbart (5) and Bernheimer (6). Antistreptolysin $O$ determinations were made according to the method of Todd (7) with minor modifications, and antistreptokinase titrations were carried out as described by Christensen (8).

\section{EXPERIMENTAL}

Effect of heating on streptolysin $S$ inhibitor in serum. The titer of inhibitor in normal human serum was not changed after heating at $56^{\circ} \mathrm{C}$. for two hours. At higher temperatures, approaching the coagulation point of serum $\left(60-65^{\circ} \mathrm{C}\right.$.), there 
was frequently an increase in titer as great as twofold. Coagulation of the sera by heating at 70 $100^{\circ} \mathrm{C}$. resulted in complete loss of inhibition of streptolysin $\mathrm{S}$.

Streptolysin $S$ inhibition by human and animal sera. The levels of streptolysin $\mathrm{S}$ inhibitor in the presumably normal serum of various species of animals and of man are presented in Table $I$. The sera of all species tested were found to be inhibitory. It is notable that the titers of dog sera were considerably higher than those of any other species tested.

Effect of injecting rabbits with streptolysin $S$ on the titer of streptolysin $S$ inhibitor. To determine whether the streptolysin S employed in this study was antigenic, six rabbits were given repeated subcutaneous injections. One $\mathrm{mg}$. of streptolysin $S$ in a volume of $1 \mathrm{ml}$. was injected twice weekly for two weeks followed by a rest period of two weeks. A total of 12 injections was given in this manner over a period of three months. The animals were bled immediately before the injections were started and once each month thereafter. No change in titer of streptolysin $\mathrm{S}$ inhibitor was observed.

A second group of six rabbits was injected intravenously with streptolysin $S$ in a dose of $0.8 \mathrm{mg}$. per $\mathrm{Kg}$. of body weight at each injection. The toxin was administered twice weekly in a concentration of $1 \mathrm{mg}$. per $\mathrm{ml}$. A total of nine injections was given to three of the animals. Three rabbits died before the course of injections could be completed. The remaining three showed no evidence of change from normal values for streptolysin $\mathrm{S}$ inhibitor either during or following the administration of the toxin.

Immunization of rabbits with live cultures of beta hemolytic streptococci. Todd (9) demonstrated a marked rise in "antistreptolysin S" titer

TABLE I

Inhibition of streptolysin $S$ by serum of normal animals

\begin{tabular}{l|c|c|c}
\hline \hline \multicolumn{1}{c|}{ Animal } & $\begin{array}{c}\text { No. of } \\
\text { sera }\end{array}$ & $\begin{array}{c}\text { Mean titer } \\
\text { units/ml. }\end{array}$ & $\begin{array}{c}\text { Range } \\
\text { units/ml. }\end{array}$ \\
\hline Rabbit & 36 & 10.3 & $5.6-20$ \\
Horse & 5 & 18.4 & $16-20$ \\
Rat & 5 & 20 & $16-25$ \\
Guinea pig & 6 & 9.8 & $3-33$ \\
Chicken & 2 & 15.9 & $15-16.7$ \\
Dog & 5 & 55.2 & $40-83.3$ \\
Human & 40 & 14.5 & $10-20$ \\
\hline
\end{tabular}

TABLE II

Failure of streptolysin $S$ inhibitor titers of rabbit sera to increase during immunization with live cultures of beta hemolytic streptococci (Blackmore strain)

\begin{tabular}{r|c|c|c|c}
\hline \hline $\begin{array}{c}\text { Rabbit } \\
\text { No. }\end{array}$ & $\begin{array}{c}\text { Preliminary } \\
\text { bleeding, } \\
8-5-49\end{array}$ & $\begin{array}{c}\text { After first } \\
\text { course, } \\
10-12-49\end{array}$ & $\begin{array}{c}\text { After } \\
\text { resting, } \\
11-7-49\end{array}$ & $\begin{array}{c}\text { After 2nd } \\
\text { course. } \\
1-3-50\end{array}$ \\
\hline 1 & 12.5 & 6.7 & 10.0 & 10.0 \\
2 & 10.0 & 5.0 & 6.7 & 10.0 \\
3 & 12.5 & 6.7 & 6.7 & 10.0 \\
4 & 10.0 & 5.0 & 8.0 & 10.0 \\
5 & 10.0 & 5.0 & 6.7 & 10.0 \\
6 & 12.5 & 10.0 sacrificed & -10.7 & -10.0 \\
7 & 16.0 & 6.7 & -10.0 & 16.0 \\
8 & 20.0 & 10.0 & - & - \\
9 & 13 & 6.7 died & - & - \\
10 & 13 & 6.7 died & - & - \\
\hline
\end{tabular}

Titers of streptolysin $\mathrm{S}$ inhibitor in units per $\mathrm{ml}$.

in the sera of a small proportion of a group of rabbits that had been intensively immunized with repeated doses of live cultures of Group A hemolytic streptococci. Ten rabbits were injected twice weekly, according to the schedule outlined by Todd (9), with increasing doses of whole culture of living organisms grown in neopeptone meat infusion broth for 18 hours at $37^{\circ} \mathrm{C}$. The strain of streptococcus chosen was that isolated by Todd (10) and designated "Blackmore" by him." This organism produces streptolysin $\mathrm{S}$ but does not form streptolysin $\mathrm{O}$ in demonstrable amount (11). Inhibitor titrations were made on serum obtained four days after the last injection.

Two animals died during the first course of injections and one, which developed a large orbital abscess, was sacrificed. The other rabbits lost weight, appeared ill, and, as shown in Table II, in every instance a fall in serum titer of streptolysin $\mathbf{S}$ inhibitor occurred. This observation is of interest in view of the similar behavior of the inhibitor in patients severely ill with rheumatic fever and certain other illnesses (1). After a period of rest, the seven surviving rabbits were given a second course of injections similar to the first. The second course was tolerated well and the animals did not sicken. None exhibited an elevation of inhibitor levels, but on the contrary, a reversion to the original normal levels took place. The results are summarized in Table II.

Streptolysin $S$ inhibition by serum protein fractions. Fractions of human plasma ${ }^{4}$ prepared by

${ }^{3}$ Kindly supplied by Dr. Horace Gezon.

4 Kindly supplied by Dr. J. L. Oncley. 
TABLE III

Inhibition of streptolysin $S$ by plasma fractions prepared by cold alcohol fractionation

\begin{tabular}{|c|c|c|}
\hline $\begin{array}{l}\text { Plasma fraction } \\
2 \%(\mathrm{w} / \mathrm{v}) \text { in } 0.85 \% \mathrm{NaCl}\end{array}$ & $\mid \begin{array}{c}\text { Streptolysin } \mathrm{S} \\
\text { inhibition }\end{array}$ & $\begin{array}{c}\text { Streptolysin } \mathbf{S} \\
\text { inhibition }\end{array}$ \\
\hline $\begin{array}{l}\text { Normal human serum (mean)* } \\
\text { Fraction I } \\
\text { Fraction II and III } \\
\text { Fraction II } \\
\text { Fraction III } \\
\text { Fraction IV-1 } \\
\text { Fraction IV-4 } \\
\text { Fraction IV-7 } \\
\text { Fraction V }\end{array}$ & $\begin{array}{l}\text { units } / \mathrm{ml} . \\
5.0 \\
0 \\
\text { trace } \\
0 \\
\text { trace } \\
25.0 \\
\text { trace } \\
\text { trace } \\
0\end{array}$ & $\begin{array}{c}\text { units/gm. dry wt. } \\
250 \\
0 \\
\text { trace } \\
0 \\
\text { trace } \\
1000 \\
\text { trace } \\
\text { trace } \\
0\end{array}$ \\
\hline
\end{tabular}

* Lyophilized normal serum reconstituted to contain 2 per cent serum proteins in distilled water.

the cold alcohol fractionation method of Cohn and his associates (12) were tested for streptolysin $\mathrm{S}$ inhibition. Table III shows the relative inhibitory activity of the fractions tested. It is apparent that fraction IV-1 is most active as an inhibitor of streptolysin $\mathrm{S}$ while only traces of activity are associated with fractions IV-4, IV-7 and fraction III. Fraction IV-1 and fraction III- 0 have been shown to contain most of the lipids and lipoproteins of serum (13). Although we have not tested fraction III-0, Humphrey (4) has recently reported that this fraction also contains considerable streptolysin $\mathrm{S}$ inhibitory activity. It is of significance that fraction IV-1 is about four times as active, per unit weight, in inhibiting streptolysin $S$ as whole human serum while fraction IV-4 from which lipids have been removed, contains only traces of activity.

As shown in Table III, streptolysin S inhibition was not found in fraction II which contains the gamma globulins associated with specific antibodies. Partial purification of the beta and gamma globulins of human serum was carried out by precipitation with alcohol at low temperatures according to the conditions defined by Deutsch and his associates (14). The serum fractionated in this manner was obtained from a patient convalescing from an acute streptococcal infection. The serum titers of antistreptolysin $\mathrm{O}$ and antistreptokinase were markedly elevated in this patient. The gamma globulin fraction did not inhibit streptolysin $\mathrm{S}$ but was several times as active as the original serum against streptolysin $\mathrm{O}$ and streptokinase. Appreciable inhibitory activity against streptolysin $\mathrm{S}$ was present in the beta globulin fraction.

It was estimated that the total streptolysin $S$ inhibition of the fractions prepared by the cold alcohol method was about one-third that of whole, human serum. It was also evident, from our attempts to prepare highly active fractions by this method, that the activity of the inhibitor is easily destroyed by high concentrations of alcohol. Fractionation of serum by salting out with ammonium sulfate was therefore undertaken. Precipitates were successively removed at ammonium sulfate concentrations of 0 to 33,50 to 62 and 62 to 68 per cent saturation.

The values for streptolysin $S$ inhibitor in various fractions of horse and human serum separated by means of ammonium sulfate are shown in Table IV. The greatest inhibition of streptolysin $\mathrm{S}$ is associated with the fractions of horse and human serum precipitated at ammonium sulfate concentrations exceeding 50 per cent saturation. It is also evident that the combined inhibitory activity of the fractions was much greater than that of the original serum. Following fractionation the increase in total activity of horse serum was 3.75 times, and of human serum, 2.41 times.

The fraction of horse serum showing the most activity was the euglobulin which precipitated when the supernate of the fraction precipitated at 50 per cent saturation with ammonium sulfate was dialyzed against distilled water. The inhibitory activity of this fraction was 17 times that of whole horse serum. The human serum fraction showing the highest activity was the supernate

TABLE IV

The effect of ammonium sulfate fractionation of serum on streptolysin $S$ inhibition

\begin{tabular}{|c|c|c|c|c|}
\hline \multirow{3}{*}{$\begin{array}{l}\text { Per cent saturation of } \\
\text { ammonium sulfate }\end{array}$} & \multicolumn{4}{|c|}{ Streptolysin $\mathbf{S}$ inhibition in units } \\
\hline & \multicolumn{2}{|c|}{ Horse serum } & \multicolumn{2}{|c|}{ Human serum } \\
\hline & $\begin{array}{c}\text { total } \\
\text { units }\end{array}$ & $\begin{array}{c}\text { units/mg. } \\
\text { protein }\end{array}$ & $\begin{array}{c}\text { total } \\
\text { units }\end{array}$ & $\begin{array}{c}\text { units/mg. } \\
\text { protein }\end{array}$ \\
\hline $\begin{array}{l}\text { Original serum } \\
0-33 \\
33-50 \\
\text { Euglobulin fraction* } \\
50-62 \\
62-68 \\
\text { Supernate }\end{array}$ & $\begin{array}{r}1950 \\
0 \\
\text { trace } \\
320 \\
4000 \\
3300 \\
0\end{array}$ & $\begin{array}{l}0.27 \\
0 \\
\text { trace } \\
4.6 \\
3.67 \\
2.5 \\
0\end{array}$ & $\begin{array}{r}1587 \\
0 \\
0 \\
-\quad \\
600 \\
824 \\
2400\end{array}$ & $\begin{array}{l}0.22 \\
0 \\
0 \\
-1.1 \\
0.61 \\
12.2\end{array}$ \\
\hline
\end{tabular}

* Euglobulin prepared by dialysis of the supernate of the 50 per cent saturated ammonium sulfate fraction of horse serum against distilled water. 
remaining after precipitation at 68 per cent saturated ammonium sulfate. The specific activity of this fraction was 55.5 times that of whole human serum. It should be noted that these quantitative relationships vary somewhat in individual serum samples and seem to depend largely upon relatively slight changes in conditions of fractionation.

The results of ammonium sulfate fractionations indicate that streptolysin $\mathrm{S}$ inhibition is associated with serum albumin as well as with the alpha-1 and beta-1 lipoproteins. Pedersen (15) has shown that a protein with properties in the ultracentrifuge similar to those of McFarlane's X-protein (lipoprotein) is precipitated by ammonium sulfate at 50 to 60 per cent saturation. It is probable that albumin prepared by the cold ethanol method loses its streptolysin $\mathrm{S}$ inhibition because of the high concentrations of alcohol employed, or because this albumin product is more highly purified and lipoproteins have been separated from it. It has been shown that the alpha- 1 and beta- 1 lipoproteins contained in fractions IV- 1 and III- 0 are denatured with the release of lipid on exposure to high alcohol concentrations (13) or on freezing to temperatures below $-25^{\circ} \mathrm{C}$. (16).

Since the yield of total streptolysin $\mathrm{S}$ inhibitor, following fractionation with ammonium sulfate, was much greater than that found in the original serum, the effect of recombining inactive serum fractions with those showing streptolysin $\mathrm{S}$ inhibition was studied. Inhibition by the active fractions was not altered by the addition of the inactive protein fractions to them.

The effect of ether extraction on streptolysin $S$ inhibition. The association of streptolysin S inhibition with the fractions of serum containing lipoproteins and lipids, suggested that the inhibitor might be isolated by extraction with organic solvents. To accomplish this with a minimum of protein denaturation, the method for removing lipids from serum described by McFarlane (16) was employed. This procedure removes about twothirds of the total serum lipids without altering the electrophoretic pattern of serum except for the denaturation of the alpha-1 and beta-1 lipoproteins which appear to be responsible, by virtue of their hydrophilic properties, for stabilizing serum lipids in solution.

Samples of serum and serum fractions were shaken gently with equal parts of diethyl ether and frozen at $-70^{\circ} \mathrm{C}$. in a dry ice-alcohol mixture. After thawing, the ether layer which separated was removed and the procedure repeated twice with the addition of fresh ether.

'The effect of this procedure on the inhibitor level of various serum and serum fractions is summarized in Table $\mathrm{V}$. There was a reduction of 50 to 90 per cent in inhibitory activity of the lipidextracted samples. Streptolysin $\mathrm{S}$ inhibition could not be removed completely by this method. Inhibitory activity could be recovered in the ether extracts of some of the samples studied but not in all. Recombination of the extracted material and the ether-treated serum did not result in a return of the inhibitor titer to the original values.

To determine whether lipid extraction had been accomplished without denaturation of serum proteins other than alpha-1 and beta-1 lipoproteins, the antistreptolysin $\mathrm{O}$ titer of another serum sample was tested before and after ether extraction. No change in antistreptolysin $\mathrm{O}$ titer was noted. The streptolysin $\mathrm{S}$ inhibition of the same sample was reduced to 40 per cent of the original value.

In an attempt to remove the serum lipids more completely, extraction with an ether-alcohol mixture at low temperatures was carried out as described by MacLeod and Avery (17). Using this method, 91 per cent of the streptolysin S inhibition was removed from horse serum and 70 per cent from human serum.

The effect of ether extraction of serum was further studied in order to determine whether the reduction of inhibitory action is caused by the removal of a compound soluble in ether or by some alteration in the state of the inhibitor. Samples

TABLE V

The effect of extraction of serum lipids by the ether-freezing method on streptolysin $S$ inhibition

Titer of streptolysin $\mathrm{S}$ inhibitor in units $/ \mathrm{ml}$.

\begin{tabular}{l|c|c|c}
\hline \multicolumn{1}{c|}{ Serum sample } & $\begin{array}{c}\text { Original } \\
\text { serum }\end{array}$ & $\begin{array}{c}\text { Serum after } \\
\text { extraction } \\
\text { of lipids }\end{array}$ & $\begin{array}{c}\text { Per cent } \\
\text { loss }\end{array}$ \\
\hline Rabbit 5S & 6 & 3 & 50 \\
Rabbit 7 & 12 & 3 & 75 \\
Rabbit 8 & 6 & 3 & 50 \\
Rabbit pool 3 & 6.7 & 3.3 & 50 \\
Human pool 2 & 25 & 10 & 60 \\
Old human sera pool & 50 & 5 & 90 \\
Cohn fraction IV-1 & 6 & 3 & 50 \\
Horse no. 755 & 20 & 4 & 80 \\
Horse albumin & 33 & 12.5 & 62 \\
\hline
\end{tabular}


of human and horse serum were gently shaken with equal parts of diethyl ether for five minutes at room temperature. The ether was then evaporated from the serum under reduced pressure at room temperature, leaving behind the original serum components. This procedure resulted in as great a loss of streptolysin $\mathrm{S}$ inhibitor as that which occurred when the ether-soluble materials were removed.

It is evident that streptolysin $\mathrm{S}$ inhibitor is highly sensitive to ether and that it is partially inactivated simply by adding ether to serum. This finding suggests that the effect of ether on the inhibitor is either to cause partial destruction or else to alter its relationship to other serum components.

The effect of tryptic digestion on streptolysin $S$ inhibitor in serum. The increase in the inhibitory capacity of serum, which frequently occurs upon prolonged storage at $4^{\circ} \mathrm{C}$., on heating near the coagulation point, and on fractionation with ammonium sulfate, suggested that alteration of the serum proteins may cause liberation of lipids or a change in the lipoprotein complexes which inhibit streptolysin S. Study of streptolysin S inhibition after digestion of serum by a proteolytic enzyme was therefore carried out. Trypsin was used since it does not alter the activity of streptolysin S (6). The extent of proteolysis was estimated from the amount of tyrosine liberated. Equal parts of a 0.1 per cent solution of crystalline trypsin and of undiluted serum (previously heated for one hour at $56^{\circ} \mathrm{C}$.) were incubated for four hours at $37^{\circ} \mathrm{C}$. The mixture was then tested for streptolysin $\mathrm{S}$ inhibitor, and the tyrosine content of the filtrate obtained after precipitation of remaining proteins with trichloracetic acid was measured by the method of Anson (18).

Tryptic digestion of human and of horse serum resulted in a marked increase in capacity to inhibit streptolysin S. To produce this effect, however, it was necessary to digest as much as 35 to 42 per cent of the total serum protein. When the trypsin-digested serum was shaken with ether and the latter removed by evaporation at reduced pressure, a decrease of 69 to 76 per cent in inhibition resulted. The results of these experiments are summarized in Table VI.

The effect of lecithinase on streptolysin $S$ inhibitor in serum. Human serum and egg yolk suspensions become opalescent when treated with the alpha toxin of $C l$. welchii $(19,20)$. The toxin has been identified as an enzyme which decomposes lecithin into phosphorylcholine and a diglyceride (21), and also slowly degrades sphingomyelin (22). Cephalins are unaffected by the toxin $(22,23)$. Petermann (24) has shown that the release of lipid from human serum by the action of this lecithinase parallels the breakdown of the $\mathrm{X}$-protein complex, a lipoprotein complex of human serum composed of beta-1 and alpha-1 globulins and albumin. Ahrens and Kunkel (25) demonstrated that lipid particles coalesce and reach visible size after hydrolysis of lecithin by $\mathrm{Cl}$. welchii lecithinase and that there is a definite relationship between phospholipid breakdown and production of turbidity, thus confirming the hypothesis of Macfarlane and his colleagues (20).

To determine whether the action of $\mathrm{Cl}$. welchii lecithinase on human serum might also affect streptolysin $\mathrm{S}$ inhibition the following experiments were performed.

TABLE VI

The effect of tryptic digestion on streptolysin $S$ inhibitor titer and the effect of the addition of ether and of lecithinase to the trypsin-digested samples

\begin{tabular}{|c|c|c|c|c|c|c|c|}
\hline \multirow[b]{2}{*}{ Inhibitor } & \multicolumn{7}{|c|}{ Titer of streptolysin $\mathrm{S}$ inhibitor in units per $\mathrm{ml}$. } \\
\hline & $\underset{\text { titer }}{\text { Original }}$ & $\begin{array}{l}\text { Titer after } \\
\text { tryptic } \\
\text { digestion }\end{array}$ & $\begin{array}{l}\text { Protein } \\
\text { digested }\end{array}$ & $\begin{array}{l}\text { Titer after } \\
\text { adding ether } \\
\text { to trypsin- } \\
\text { digested serum }\end{array}$ & $\begin{array}{c}\text { Loss of } \\
\text { titer }\end{array}$ & $\begin{array}{l}\text { Titer after } \\
\text { adding lecithin- } \\
\text { ase to trypain- } \\
\text { digested eerum }\end{array}$ & $\begin{array}{l}\text { Loses of } \\
\text { titer }\end{array}$ \\
\hline $\begin{array}{l}\text { Horse serum } \\
\text { Horse serum albumin } \\
\text { Human serum (G. S.) } \\
\text { Human serum (A. K.) } \\
\text { Egg yolk suspension }\end{array}$ & $\begin{array}{r}20 \\
33 \\
20 \\
16 \\
2\end{array}$ & $\begin{array}{l}160 \\
62.5 \\
40 \\
64 \\
16\end{array}$ & $\begin{array}{c}\text { per cent } \\
38 \\
80 \\
35 \\
42 \\
-\end{array}$ & $\begin{array}{l}50 \\
12 \\
12.5 \\
16.7 \\
-\end{array}$ & $\begin{array}{c}\text { per cent } \\
69 \\
81 \\
69 \\
74 \\
\end{array}$ & $\begin{array}{l}40 \\
16.7 \\
25 \\
12.5 \\
0\end{array}$ & $\begin{array}{c}\text { per cent } \\
75 \\
73 \\
38 \\
80 \\
100\end{array}$ \\
\hline
\end{tabular}


The alpha toxin of $\mathrm{Cl}$. welchii employed was a concentrated culture filtrate, containing 50 per cent glycerol as a preservative, prepared by the method of Adams and Hendee (26). This preparation, in a dilution of $1: 400$, produced opalescence in an egg yolk suspension prepared as described by Macfarlane and his co-workers (20). The toxin was diluted $1: 50$ in a gelatin-calcium-saline solution ( 0.01 per cent gelatin, $0.001 \mathrm{M} \mathrm{CaCl}_{2}$, in 0.85 per cent sodium chloride) and added to an equal volume of human serum. The mixture was incubated for 16 hours at $37^{\circ} \mathrm{C}$. As a control, a sample of the same serum was added to an equal volume of the toxin diluted 1:50 in five per cent sodium citrate in order to inhibit the lecithinase by binding calcium ions. A second control containing a $1: 1$ dilution of the same serum with 0.85 per cent saline was prepared and both controls were incubated under the above conditions. Following the incubation period, the degree of turbidity was noted and sufficient antitoxin was added to each tube to neutralize the lecithinase and thereby block its hemolytic action. The samples and controls were then tested for streptolysin S inhibition.

All 16 specimens of fresh human serum showed a marked reduction in streptolysin $\mathrm{S}$ inhibitor after treatment with lecithinase. The reduction in titer ranged from 50 to 83 per cent and averaged 60 per cent. There was no change in the titer of the control samples to which citrate had been added to inhibit lecithinase activity and no turbidity developed in these specimens. Increasing the concentration of lecithinase resulted in increased loss of streptolysin $\mathrm{S}$ inhibition but the inhibitory property of sera could not be completely destroyed. The opalescent, "milky" serum, which resulted from the action of lecithinase, was clarified by high-speed centrifugation. The clear serum contained all of the residual inhibitor and the separated fatty material was inactive. Repeated treatment of the clarified serum with lecithinase failed to completely destroy its inhibitory activity, although 80 per cent of the activity could be removed in this way. In contrast to human serum, horse serum developed neither opalescence nor loss of streptolysin $\mathrm{S}$ inhibition when treated with lecithinase. It has been reported by Nagler (19) that horse and most other animal sera do not become turbid on adding $\mathrm{Cl}$. welchii alpha toxin to them although Crook (27) has shown that under certain conditions these sera may show the Nagler reaction.

Exposure of the trypsin-digested serum and serum fractions to lecithinase resulted in a marked reduction of the high streptolysin $\mathrm{S}$ inhibitor titer of these samples. The results of this experiment are also included in Table VI.

The activity of lipids, related substances and tissue extracts as inhibitors of streptolysin $S$. The preceding observations indicated that lecithin, and perhaps other phospholipids, may play a significant role in the inhibition of streptolysin $S$ by serum. The activity of various lipids as inhibitors was therefore tested.

Egg yolk suspensions were prepared by the method of Macfarlane (20). Crude ovolecithin was made by precipitation of egg yolks with cold acetone, as described by Macfarlane and Knight (21), with minor modifications. This preparation probably contained significant amounts of sphingomyelin and cephaline as well as lecithin. The "pure" lecithin tested was a highly purified product derived from egg yolk which assayed at 100 per cent lecithin when phosphorus content was used as a criterion of purity and at about 87 per cent lecithin on the basis of choline content (28). Phosphatidyl serine, a purified fraction of "brain cephalin" (29), and a highly purified preparation of sphingomyelin (28) were also tested. Saline suspensions of the various phospholipids were prepared by dissolving the material in absolute alcohol or ether and adding it dropwise to a measured volume of boiling saline.

The tissue extracts were prepared from fresh, normal rabbit organs. A 10 per cent (wt./vol.) suspension of each organ in 0.85 per cent sodium chloride was prepared by maceration of the tissues in a Waring blendor for 10 minutes followed by centrifugation in a No. 2 International centrifuge at 3,000 r.p.m. for 20 minutes. After removal of the surface layer of fat, the supernate was decanted and tested for streptolysin $S$ inhibition. The fat

TABLE VII

Streptolysin $S$ inhibition by lipids and related substances and by rabbit tissue extracts

\begin{tabular}{|c|c|c|c|}
\hline Substance & $\begin{array}{l}\text { Strepto- } \\
\text { lysin S } \\
\text { inhibition }\end{array}$ & $\begin{array}{c}\text { Rabbit tissue } \\
\text { saline suspension } \\
(10 \% w / v)\end{array}$ & $\begin{array}{l}\text { Strepto- } \\
\text { lysin S } \\
\text { inhibition }\end{array}$ \\
\hline $\begin{array}{l}\text { "Crude" ovolecithin } \\
\text { "Pure" ovolecithin" } \\
\text { Phosphatidyl serinet } \\
\text { Sphingomyelint } \\
\text { Cholesterol } \\
\text { Neutral fat } \\
\text { Choline } \\
\text { Egg yolk suspension }\end{array}$ & $\begin{array}{c}\text { units/mg. } \\
2.0 \\
3.5 \\
\\
1.0 \\
0.8 \\
0.0 \\
0.0 \\
0.0 \\
\text { trace }\end{array}$ & $\begin{array}{l}\text { Tissue fat } \\
\text { Muscle } \\
\text { (psoas) } \\
\text { Brain } \\
\text { Lung } \\
\text { Heart } \\
\text { Kidney } \\
\text { Liver } \\
\text { Adrenal } \\
\text { Ovary } \\
\text { Testis } \\
\text { Lymph nodes } \\
\text { (popliteal) } \\
\text { Thyroid } \\
\text { Spleen }\end{array}$ & $\begin{array}{c}\text { units/ml. } \\
0 \\
0 \\
4 \\
2.5 \\
2 \\
2 \\
2.5 \\
16 \\
33 \\
10 \\
5 \\
0 \\
0\end{array}$ \\
\hline
\end{tabular}

* Prepared and kindly supplied by Dr. M. Pangborn.

$\dagger$ Prepared and kindly supplied by Dr. J. Folch-Pi.

$\ddagger$ Prepared and kindly supplied by Dr. B. B. Brodie. 
removed from the various organ suspensions was tested for streptolysin $S$ inhibition as a 10 per cent suspension (wt./vol.) in isotonic saline.

The results are summarized in Table VII. The greatest inhibition of streptolysin $\mathrm{S}$ was produced by suspensions of lecithin. The inhibitory activity of purified lecithin was 3.5 units per mg. as compared with 1.0 unit per mg. for phosphatidyl serine and 0.8 units per $\mathrm{mg}$. for sphingomyelin. Egg yolk suspensions showed only a trace of inhibitory activity while cholesterol, neutral fat and choline were completely inactive.

The tissue suspensions showing the highest titers of streptolysin $\mathrm{S}$ inhibition were those prepared from ovary, adrenal and testis. Lung, heart, kidney and liver contained significant quantities of blood which could account in part for the slight inhibition shown by extracts of these organs. Preparations of tissue fat were inactive as inhibitors.

Hewitt and Todd (30), and recently Humphrey (4), demonstrated that the activity of ovolecithin as an inhibitor of streptolysin $\mathrm{S}$ is neutralized when lecithin is added to serum. The following experiment also confirms the neutralizing effect of serum and serum fractions on inhibition by egg yolk lecithin.

Egg yolk lecithin was suspended in 0.85 per cent sodium chloride in a concentration of $50 \mathrm{mg}$. per $\mathrm{ml}$. and twofold dilutions were prepared. An equal volume of each dilution was added to serum and to a 5 per cent solution of Cohn fraction V (albumin). One volume of lecithin ( $3 \mathrm{mg}$. per $\mathrm{ml}$.) was also added to equal volumes of 2 per cent solutions of fraction IV-1 and of fraction IV-4. The suspensions of varying amounts of lecithin in constant amounts of serum proteins were titrated for inhibitory activity.

Whole serum and the various serum fractions that were tested greatly reduced the inhibition of streptolysin S by lecithin, particularly at low concentrations of the latter. The percentage reduction of the inhibitory activity of lecithin, which occurred when serum was added, ranged from 50 per cent at a lecithin concentration of $25 \mathrm{mg}$. per ml., to almost 100 per cent at a lecithin concentration of $1.7 \mathrm{mg}$. per ml. Five per cent albumin solutions and 2 per cent solutions of fraction IV -1 and IV -4 also exerted a similar neutralizing effect on the inhibitory activity of lecithin.

In connection with this experiment it was of interest to study the effect of trypsin digestion on egg yolk suspensions. It was observed, contrary to expectation, that egg yolk suspensions, rich in lecithin produced only slight inhibition of streptolysin (see Table VI). Because of the neutralizing action of serum proteins on the inhibitory action of lecithin, it seemed possible that digestion of egg yolk by proteolytic enzymes might increase its activity as an inhibitor through the liberation of lecithin bound in an inactive form. As shown in Table VI, a suspension of egg yolk, which originally showed only a trace of inhibitory activity, developed a titer of 16 units per ml. after treatment with trypsin. Moreover, treatment of the trypsin-digested egg yolk suspension with lecithinase resulted in complete loss of inhibitor. It would appear, therefore, that the reactions of egg yolk suspensions and of serum to digestion by trypsin and lecithinase are similar.

The effect of alternate treatment of serum with trypsin and ether. Since tryptic digestion of serum increases streptolysin $\mathrm{S}$ inhibition and the trypsin-digested serum is, in turn, greatly reduced in inhibitor by saturation with ether, an experiment was performed to determine the effect of repeated, alternate treatment of serum with trypsin and with ether.

Four samples of fresh human serum were shaken with equal parts of ether for five minutes at room temperature and the mixture freed of ether by evaporation under reduced pressure. All samples showed a reduction of streptolysin S inhibition of about 65-75 per cent. The ethertreated samples were then digested with a 0.25 per cent solution of crystalline trypsin for four hours at $37^{\circ} \mathrm{C}$. All showed a rise in titer to approximately the original values of the undigested sera. Subsequent treatment with ether and trypsin, however, had no further effect and the titer remained constant. In a second experiment the order was reversed and the sera were treated first with trypsin. A three-fold increase in titer resulted and this was, in turn, reduced by treatment of the trypsin-digested samples with ether. Subsequent re-treatment with trypsin and ether had no further significant effect on streptolysin $\mathrm{S}$ inhibition.

It appears that the effect of trypsin and ether upon serum inhibitor is complete with the initial exposure of serum to these agents under the above conditions and that the effects of each on the streptolysin S inhibitor cannot be repeated a second time. Trypsin apparently destroys proteins which have a neutralizing effect on the serum in- 
hibitor both before and after treatment of the serum with ether. Ether, in turn, partially inactivates the serum inhibitor both before and after tryptic digestion of serum.

\section{DISCUSSION}

The foregoing results show that the inhibition of streptolysin $\mathrm{S}$ by serum is due to normal components of serum rather than to a specific antibody. The sera of all normal animal species that have been tested are capable of inhibiting streptolysin $\mathrm{S}$ and the inhibition has been demonstrated to be independent of gamma globulin fractions in humans, rabbits and horses.

The association of streptolysin $\mathrm{S}$ inhibitor with Cohn fractions IV-1 and III-0, which contain the alpha-1 and beta-1 lipoproteins, suggests that it is of lipid nature, especially since alpha and beta globulin fractions, from which lipid has been removed, lose most of their inhibitory activity. Among the various lipids known to be present in plasma fractions III-0 and IV-1, only the phospholipids, and particularly lecithin, inhibit streptolysin S. In addition, the decomposition of lecithin in serum by the action of a lecithinase (alpha toxin of $\mathrm{Cl}$. welchii) results in a marked reduction of inhibitor.

An increase in the inhibitory titer of serum follows alteration of serum proteins by tryptic digestion, ammonium sulfate fractionation, heating near the coagulation point and prolonged storage at or above $4^{\circ} \mathrm{C}$. The increased titer can be greatly reduced, in each instance, by the action of $\mathrm{Cl}$. welchii lecithinase.

Studies now in progress indicate that certain human sera which contain high concentrations of phospholipids also show an increase in inhibitor (31). The highest titers in human sera have been observed in the sera of patients with biliary cirrhosis $^{5}$ (31). These sera show not only very high phospholipid concentrations, but a striking increase in the beta globulins associated with serum lipids (32). Conversely, several serum samples, including those of patients with rheumatic fever, which had a low titer of streptolysin $S$ inhibitor, were also below normal in serum phospholipid content. Dog sera, which normally contain phospholipid in a concentration almost twice

\footnotetext{
5 Kindly supplied by Dr. H. G. Kunkel.
}

as high as human sera (33), show high values for inhibitor whereas normal rabbit sera, low in phospholipid, are also relatively low in streptolysin $\mathrm{S}$ inhibition.

Although the foregoing experiments strongly implicate phospholipids as substances which play an important role in the inhibition of streptolysin $\mathrm{S}$, certain observations indicate that the inhibitor in the serum of all animal species may not be identified definitely as lecithin itself. Humphrey (4) found that streptolysin S inhibition did not correlate quantitatively with the "total lipid phosphorus" content of the sera of several animal species. Also, when ovolecithin is added to whole serum or serum proteins, in a concentration equivalent to the normal values for serum lecithin, its inhibitory activity is reduced to a value much below the normal titer. Finally, the addition of ether to serum, followed by its evaporation, without the removal of any of the original serum components, results in a marked loss of inhibitor.

The fact that the inhibitory action of lecithin is neutralized when the lipid is added to serum proteins in vitro does not preclude the possibility that lecithin may be "metabolically" bound as a lipoprotein in such a manner as to exert an inhibiting effect upon the toxin, even in the presence of other proteins. The reduction of inhibitor caused by treatment of serum with ether, both before and after tryptic digestion, is not, however, consistent with the assumption that lecithin itself is the inhibitor.

The following hypothesis is tentatively advanced to explain the above observations. Virtually all phospholipid is found in the serum fractions containing the alpha- 1 and beta- 1 lipoproteins, and these fractions are associated with streptolysin $\mathrm{S}$ inhibition. It is perhaps reasonable to suggest, therefore, that the inhibitor exists as a phospholipoprotein complex. One might further assume that the active part of the complex consists of phospholipids, particularly lecithin, since other substances such as cholesterol and neutral fats do not inhibit streptolysin S. The inhibitory activity of the lipoprotein complex may be partially neutralized by certain serum proteins which upon tryptic digestion are destroyed, thus freeing additional active, inhibitory groups. Ether may dissociate lecithin from the complex, or in some other way disrupt its physical state, and thus ac- 
count for the fall in streptolysin $\mathrm{S}$ inhibition which occurs upon treatment of serum with ether. Lecithinase may also disrupt this complex and destroy its inhibitory activity, either directly by the decomposition of the lecithin moiety of the complex, or secondarily by alteration of the physical state which occurs when lecithin is destroyed. A marked change in the physical state of serum lipids has been shown to accompany the loss of lecithin as a stabilizing agent for lipid-protein emulsions $(20,25)$. The diminution of the titer of inhibitor, which results from the action of lecithinase upon serum, may therefore be secondary to the loss of this property of lecithin rather than to the loss of the direct inhibiting action of lecithin itself. Petermann (24) has shown that the release of lipid from human serum by the action of $\mathrm{Cl}$. welchii lecithinase parallels the breakdown of the X-protein complex, a lipoprotein complex characteristic of human serum and composed of alpha-1 and beta-1 lipoproteins and albumin.

The hypothesis, therefore, that streptolysin $\mathrm{S}$ inhibitor is a lipoprotein complex, and that the phospholipids play a role in its stabilization as well as in its composition, would appear to be in agreement with the available experimental evidence.

Our results are in agreement with the recent independent observations of Humphrey $(3,4)$ who has presented evidence indicating that "antistreptolysin $S$ " is present in the normal serum of numerous animal species and has demonstrated its association with the fractions of serum rich in lipoprotein.

In agreement with Humphrey's findings (3), we have also been unable to demonstrate the appearance of specific antibodies to streptolysin $\mathrm{S}$ after immunizing rabbits with live cultures of beta hemolytic streptococci. Although it appears from Todd's experiments (9) that some rabbits may show a high degree of streptolysin $\mathrm{S}$ inhibition following intensive "immunization" with live cultures of beta hemolytic streptococci, specific antibodies do not appear to play a significant role in the neutralization of streptolysin $\mathrm{S}$ in streptococcal disease (1).

It is possible that streptolysin $\mathrm{S}$ inhibitor in serum may be of some importance in affording protection against the noxious effects of streptolysin
$\mathrm{S}$, and may play a part in natural resistance to streptococcal disease. It also appears that the fall in streptolysin S serum inhibitor which occurs in most patients during the course of rheumatic fever $(1,2)$ may reflect a temporary disturbance of lipid metabolism.

\section{SUMMARY}

1. The inhibition of streptolysin $S$ is due to normal components of serum rather than to a specific antibody. The sera of a wide variety of normal animal species inhibit streptolysin $S$ and this inhibition is independent of gamma globulins in the sera of humans, rabbits and horses. Specific antibodies to streptolysin $\mathrm{S}$ did not appear when rabbits were injected with streptolysin $S$ or with live cultures of beta hemolytic streptococci.

2. The highest degree of streptolysin $\mathrm{S}$ inhibition appears in the fractions associated with alpha-1 and beta- 1 lipoproteins when serum is fractionated by the cold alcohol method. When serum is fractionated by salting out with ammonium sulfate, the albumin fraction is also associated with streptolysin S inhibition. Saline suspensions of phospholipids, particularly lecithin, inhibit streptolysin $\mathrm{S}$.

3. A marked reduction of streptolysin $\mathrm{S}$ inhibition occurs when serum is treated with $\mathrm{Cl}$. welchii lecithinase, or with ether or ether-alcohol mixture.

4. Inhibition of streptolysin $S$ by serum is increased by tryptic digestion, by heating near the coagulation point, by prolonged storage at or above $4^{\circ} \mathrm{C}$. and by fractionation with ammonium sulfate. Following fractionation with ammonium sulfate, the increase in total inhibitory activity of horse serum was 3.75 times, and of human serum 2.41 times. In each instance, treatment with lecithinase or with ether produces a marked decrease in streptolysin $\mathrm{S}$ inhibition.

5. The streptolysin $S$ inhibitor in serum appears to be composed of a phospholipoprotein complex and the phospholipids of serum may play a role in its stabilization as well as in its composition.

\section{BIBLIOGRAPHY}

1. Stollerman, G. H., and Bernheimer, A. W., The inhibition of streptolysin $\mathrm{S}$ by the serum of patients with rheumatic fever and acute streptococcal pharyngitis. J. Clin. Invest., 1950, 29, 1147. 
2. Todd, E. W., Coburn, A. F., and Hill, A. B., Antistreptolysin $\mathrm{S}$ titers in rheumatic fever. Lancet, 1939, $2,1213$.

3. Humphrey, J. H., The nature of antistreptolysin $\mathrm{S}$ in the sera of man and of other species. Antistreptolysin titres in normal and diseased states. Brit. J. Exper. Path., 1949, 30, 345.

4. Humphrey, J. H., The nature of antistreptolysin $\mathrm{S}$ in the sera of man and of other species. The lipoprotein properties of antistreptolysin S. Brit. J. Exper. Path., 1949, 30, 365.

5. Bernheimer, A. W., and Rodbart, M., The effect of nucleic acids and of carbohydrates on the formation of streptolysin. J. Exper. Med., 1948, 88, 149.

6. Bernheimer, A. W., Formation of a bacterial toxin (streptolysin S) by resting cells. J. Exper. Med., 1949, 90, 373.

7. Todd, E. W., Antigenic streptococcal hemolysin. J. Exper. Med., 1932, 55, 267.

8. Christensen, L. R., Methods for measuring the activity of components of the streptococcal fibrinolytic system, and streptococcal desoxyribonuclease. J. Clin. Invest., 1949, 28, 163.

9. Todd, E. W., The differentiation of two distinct serological varieties of streptolysin, streptolysin O and streptolysin S. J. Path. \& Bact., 1938, 47, 423.

10. Todd, E. W., Streptolysins of various groups and types of hæmolytic streptococci; serological investigation. J. Hyg., 1939, 39, 1.

11. Herbert, D., and Todd, E. W., The oxygen-stable hæmolysin of Group A hæmolytic streptococci (streptolysin S). Brit. J. Exper. Path., 1944, 25, 242.

12. Cohn, E. J., Strong, L. E., Hughes, W. L., Jr., Mulford, D. J., Ashworth, J. N., Melin, M., and Taylor, H. L., Preparation and properties of serum and plasma proteins. IV. A system for the separation into fractions of the protein and lipoprotein components of biological tissues and fluids. J. Am. Chem. Soc., 1946, 68, 459.

13. Edsall, J. T., Advances in Protein Chemistry edited by Anson, M. L., and Edsall, J. T. Academic Press, Inc., New York, 1947, Vol. III.

14. Deutsch, H. F., Alberty, R. A., and Gosting, L. J., Biophysical studies on blood plasma proteins. IV. Separation and purification of a new globulin from from normal, human plasma. J. Biol. Chem., 1946, 165, 21.

15. Pedersen, K. O., Ultracentrifugal Studies on Serum and Serum Fractions. Almquist and Wiksells, Uppsala., 1945.

16. McFarlane, A. S., Behavior of lipoids in human serum. Nature, 1942, 149, 439.
17. MacLeod, C. M., and Avery, O. T., The occurrence during acute infections of a protein not normally present in the blood. II. Isolation and properties of the reactive protein. J. Exper. Med., 1941, 73, 183.

18. Anson, M. L., The estimation of pepsin, trypsin, papain and cathepsin with hemoglobin. J. Gen. Physiol., 1938-39, 22, 79.

19. Nagler, F. P. O., Observations on a reaction between the lethal toxin of $\mathrm{Cl}$. welchii (type A) and human serum. Brit. J. Exper. Path., 1939, 20, 473.

20. Macfarlane, R. G., Oakley, C. L., and Anderson, C. G., Hæmolysis and the production of opalescence in serum and lecithovitellin by the toxin of $\mathrm{Cl}$. welchii. J. Path. \& Bact. 1941, 52, 99.

21. Macfarlane, M. G., and Knight, B. C. J. G., The biochemistry of bacterial toxins. I. The lecithinase activity of $\mathrm{Cl}$. welchii toxins. Biochem. J., 1941, $35,884$.

22. Macfarlane, M. G., Biochemistry of bacterial toxins; enzymic specificity of Clostridium welchii lecithinase. Biochem. J., 1948, 42, 587.

23. Zamecnik, P. C., Brewster, L. E., and Lipmann, F., A manometric method for measuring the activity of the $\mathrm{Cl}$. welchii lecithinase and a description of certain properties of this enzyme. J. Exper. Med., 1947, 85, 381.

24. Petermann, M. L., Effect of lecithinase on human serum globulins. J. Biol. Chem., 1946, 162, 37.

25. Ahrens, E. H., Jr., and Kunkel, H. G., The stabilization of serum lipid emulsions by serum phospholipids. J. Exper. Med., 1949, 90, 409.

26. Adams, M. H., and Hendee, E. D., Methods for production of the alpha and theta toxins of Clostridium welchii. J. Immunol., 1945, 51, 249.

27. Crook, E. M., The Nagler reaction: the breakdown of lipoprotein complexes by bacterial toxins. Brit. J. Exper. Path., 1942, 23, 37.

28. Brodie, B. B., Personal communication.

29. Folch, J., The isolation of phosphatidyl serine from brain cephalin, and identification of the serine component. J. Biol. Chem., 1941, 139, 973.

30. Hewitt, L. F., and Todd, E. W., The effect of cholesterol and of sera contaminated with bacteria on the hæmolysins produced by hæmolytic streptococci. J. Path. \& Bact., 1939, 49, 45.

31. Stollerman, G. H., Unpublished data.

32. Kunkel, H. G., and Ahrens, E. H., Jr., The relationship between serum lipids and the electrophoretic pattern, with particular reference to patients with primary biliary cirrhosis. J. Clin. Invest., 1949, 28, 1575.

33. Kendall, F. E., Personal communication. 